\title{
Design Principles for the Professional Development of Teacher Educators: Illustrations of Narration, Dialogue and Self-study
}

\begin{abstract}
SUMMARY
Teacher education has been recognized increasingly as a profession that fundamentally differs from teaching pupils in schools. This has resulted in teacher educator development programs which address the uniqueness of the profession. In this article we depart from this recognition of teacher education as a profession outlining the specifics of teacher education, and we describe a professional development program for teacher educators run in the Netherlands. We describe its building blocks and three design principles - narrative inquiry, dialogue and self-study - and illustrate their value by examples of evaluations taken from the program.
\end{abstract}

KEYwords: Professional Development, Dialogue, Self-Study

\section{Introduction}

Over the last two decades, there is an increasing interest in what it means to become a teacher educator (Murray \& Male, 2005; Zeichner, 2005; Swennen \& Van der Klink, 2009; Loughran, 2011). Stories of teacher educators are shared around the world illustrating the unique pathways and challenges of what it means to develop an identity as teacher educator (Churukian \& Lock, 2000; Bullough, 2010). It is now widely recognized that the identity of teacher educators is different from that of school teachers and other academics (Loughran, 2006; Swennen, Jones \& Volman, 2010). Murray and Male (2005) distinguish between the work of teachers, as first order teaching, and the work of teacher educators as second order teaching: "As second-order practitioners teacher educators induct their students into the practices and discourses of both school teaching and teacher education" (p. 126). Being a second order practitioner demands high standards of 'being able to teach as you preach', but also to preach as you teach (Swennen, Lunenberg \& Korthagen, 2008) and explicit modelling (Loughran \& Berry, 2005). Also, being a teacher educator means 
crossing boundaries between theories and practices, between visions and concrete systems, and between rituals and renewal. Teacher educators need to develop a helicopter view, and provide broadening perspectives on teaching and learning for (new) teachers to develop their own pedagogical strategies and professional identities. This means that at its core the work of teacher educators is multi-faceted (Smith, 2011) and they meet tensions and dilemmas for which each teacher educator has to find their own solutions (Berry, 2009).

The development of teacher education as a separate profession within the educational landscape has led to several initiatives to provide for the induction and professional development of teacher educators. Associations and networks of teacher educators are established, like the Association of Teacher Education in Europe (ATEE), the Dutch Association of Teacher Educators (Velon) and Info-Ted. These networks offer opportunities for teacher educators to learn and develop through journals, conferences and summer courses. Moreover, in European countries like Belgium and the Netherlands professional standards for teacher educators sometimes related to a professional registration system, have been developed (Koster, Dengerink, Korthagen \& Lunenberg, 2008; Velov, 2012) which also offer possibilities for professional development for teacher educators. In addition to more informal opportunities for professional development of teacher educators, several authors suggested institute based courses and formal induction (Smith, 2003; Van Velzen, Van der Klink, Swennen \& Yaffe, 2010; Boyd, Harris \& Murray, 2011). In 2012 scholars from the Vrije Universiteit Amsterdam, like Mieke Lunenberg and Jurriën Dengerink, took the initiative to design and implement a professional development program in the form of a course for teacher educators. The program aims at beginning and more experienced teacher educators in the Netherlands, both teacher educators in institutions and schools. The authors of this paper have been involved in the program as coordinators and teachers. In the following, we describe this program by sketching the outline of the program and highlighting the design principles: narration, dialogue and selfstudy. Also, we illustrate how these design principles work and show their effects by excerpts of evaluation data. We conclude by formulating our vision on teacher education as essentially research-based.

\section{Outline of the program}

Participants of the program are beginning and experienced teacher educators working as mentors of student teachers in schools and/or teacher educators in institutes. Although the context of their work and personal involvement in educating teachers differs, many of these teacher educators are involved 
in coordinating teacher education curricula and materials, supervising and mentoring student teachers, initiating and supporting professional networks of teacher educators and organizing ongoing professional development activities. Professional development of teacher educators is defined as a process of continuing professional development (European Commission, 2013). Shulman and Shulman (2014) describe professional development as a process that is individual and collective. At the individual level, professional development aims at reflection on personal visions, motivations, theories and practices. At the collective level, professional development expands to developing a shared vision, acknowledging a professional knowledge base and standards, and becoming part of a community of teacher educators based on shared commitment. The professional development program presented here can be understood as aiming for identity development and autonomy on the individual level, and raising awareness of professional others and systems on the collective level. It seeks both the transmission of theory and models, as well as a transition to community-based professionalism and transformation of teacher educators' stances from restricted experiential professionalism towards more extended professionalism rooted in processes of meaning-making by reflection and self-study (cf. Kennedy, 2005; Evans, 2008).

The program is modular and currently consists of eight parts: four basic modules, two follow-up modules, and two masterclasses. The basic modules aim for transmitting the knowledge base of teacher education in the Netherlands, building a community of practice with the participants, and transformation toward a reflective professional. The follow-up modules are aimed at deepening basic elements of the knowledge base by extending both theory and practice on issues such as coaching towards self-regulation, dialogic skills, and team teaching. The exact issues discussed depend on the professional development needs of the participants. The masterclasses aim at exchanging ideas and discussing topical concerns such as 'New Forms of Teacher Education' and 'Paradigms of Teacher Education'. The modular nature of the program allows for optimal flexibility for varying participants to enter the program. In general, modules are offered once or twice a year, and can be combined in any order. The types of modules differ in the time they take: basic modules take two to three days whereas follow-up modules take one day, and masterclasses are limited to half a day. All modules are open to all kinds of teacher educators and as a result every course represents a mixture of backgrounds, careers, and specialties. Sometimes, singular or combined models are offered in-company thus allowing for professional development of whole teams. 
The four basic modules can be followed separately, or in any combination. The basic modules address (1) Pedagogy of teacher education, (2) Coaching, (3) Self-study, and (4) Professional development. In the first module, participants learn to verbalize their own processes of and experiences with educating (preservice) teachers, and get to know theory and models on second-order teaching, and meaningful reflection, and relating theory with practice. In the module on coaching, participants focus on mentoring individual or groups of (pre-service) teachers and are introduced to theories and new practices of designing and performing learning dialogues. In the module on self-study, participants focus on aspects they experience as difficult in their teacher education practice, and set up and conduct a small-scale study. They collect small amounts of data, for instance audio-recordings of moments of supervision, and analyse these data to answer questions such as 'Do I support meaningful reflection?' and 'What kinds of questions do I pose?'. In the module on professional development participants get acquainted with models and theories on the teacher education profession and look ahead to their own professional development. They articulate their teacher educator identities, reflect on their tasks and competences, and are formally assessed for the national register of teacher educators.

\section{Design principles of the program}

The program has now run for eight years (starting with basic modules and seminars in 2012, and the entire program since 2016). Each year, evaluation data have been collected for the purpose of improvement. The data encompass 12 written reflections from the year 2019-2020 and 68 questionnaires with closed and open questions on the participants' experiences with and their valuing of both the form and content of the modules. The data are used for regular evaluation redesign of (parts of) the program and not so much as the input for systematic effect studies. In general, the modules of the program receive high mean scores ranging between 4.5 and 5.0 on five scale items. In the following, we present three underlying design principles which seem to explain for its success, and illustrate them with excerpts taken from qualitative data.

\section{Design principle 1: Narrative inquiry}

The first design principle interweaved in parts of the program is narrative inquiry. It is generally defined as forms of capturing information in oral, written or visualized narrative structures by a coherent plot with underlying determining characteristics such as time, setting, agents and action (McEwan \& Kegan, 1995), and in the context of teacher education specifically boils down to narrating for the purpose of developing insight in identity and personal 


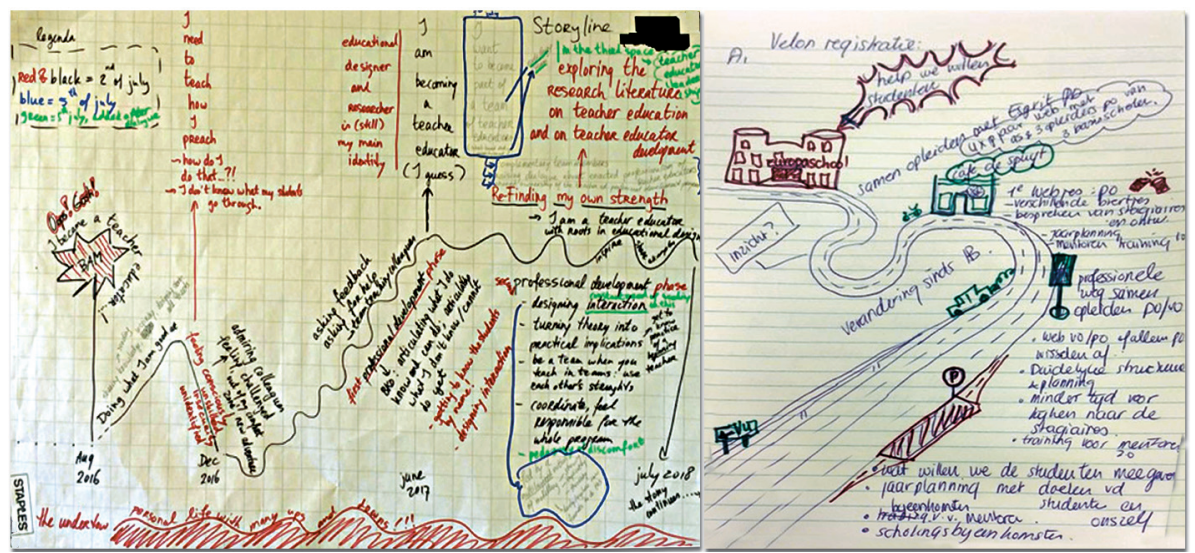

Figure 1. Two examples of visual narratives (module Registration)

practical knowledge (Kitchen, Parker \& Pushor, 2011). In the beginning of the module on professional development the participants draw their story of how they became teacher educators. In their own preferred ways they envision a timeline, decisive moments, actors and contexts to explicate their process of becoming a teacher educator. Fig. 1 shows two examples of such stories.

In the story on the left, colours have been used to show a layered story drawn at three different moments in a masterclass. The story explicates the start of being a teacher educator, and the teacher educator's growth towards team teaching. In the story on the right, a road has been drawn showing formal and informal moments in a school-university relationship central to the teacher educator's career. Both stories mark facts and moments as well as personal evaluations. The power of narration seems that it allows for teacher educator identities "under construction" to become visible and verbalized, as a consequence becoming available for further reflection.

\section{Design principle 2: Dialogue}

With numbers of participants between 10 to 20, optimal opportunities are created for dialogic learning. Raising dialogue between teacher educators is expected to have several effects. First, meeting other teacher educators working under different circumstances gives rise to reflection on one's own profession. It motivates comparison between practices and underlying attitudes and visions. What often remains implicit in how we work, now becomes explicated, and the teacher educators become each other's critical friends. Second, it allows for community-building which provides a base for continuing professional development after modules have finished. One participant stated that the 
program had made his work as a school-based teacher educator less lonely. The following citations also represent the values of professional dialogue:

"The contacts between the participants led to several supervision moments and gave rise to opportunities for reflection".

"I have changed. I thought I would just follow a training, I didn't expect myself to change. I met colleagues from other parts of the country and different institutions and it worked really well for me to participate in this group, brainstorm with them, share experiences with them, and learn from each other".

\section{Design principle 3: Self-study}

One of the modules is specifically aimed at setting up and conducting selfstudy according to its principles (Koster \& Van den Berg, 2014; Ritter et al., 2018). In the other modules self-study is referred to as a way of professionalization, sometimes in the context of broader research frameworks such as action research and research-based teacher education. Although participants are sometimes scared of 'doing research', self-study allows them to experience that it can be really small and doable and lead to useful insights. In the self-study module, participants formulate their own research question closely related to their personal experiences and practices:

"At first, I felt a bit worried about the research module. But I have learned a lot and really enjoy doing research now, I see opportunities everywhere around me".

"The coaching module was really useful, because my coaching until then was rather superficial. And in the research module I did a small study on my coaching with students, which gave me new insights".

\section{Conclusion and discussion}

Professional development to be effective needs to be designed according to a 'theory of change' running from characteristics of the intervention to expected outcomes in terms of increased knowledge and performance and positive learning effects (Kirkpatrick, 1994; Wayne et al., 2008; Desimone, 2009). In this article we described and explained a Dutch program for teacher educator professional development by its modules and underlying design principles. We illustrated in a nutshell the positive effects the program seems to have on the knowledge, skills and attitudes of the participants and their actual performance. In the future it would be worthwhile to also measure the impact of the program in terms of the observations of actual changes in the teacher educator practices, and following from that learning effects of the (student) teachers of the participating teacher educators. It could also be interesting to further explore possibilities for increasing the modular and 
flexible nature of the program by adding online activities in advance of the program or as a follow-up for alumni. Kelly et al. (2016) describe interesting ideas for online future teacher education. By offering an alumni network, we could further promote our theory of change, in which the exchange of stories between members of a professional community is viewed essential in continuing professional development.

Different models and visions or paradigms exist on how to build an effective professional development program (Kennedy, 2005). The program described here approaches the professional development of teacher educators as one evolving around dilemma's between system aspects, and personal stances (cf. Berry, 2009). At the core of this seems the teacher educator as a bridge between theory and practice. In our view, theory is at the heart of teacher education (Sjölie, 2014), and the professional development of teacher educators necessarily evolves around theories to be put in practice, or practices to be deepened and understood by theory. The program described here can therefore be viewed as research-based (cf. Cochran-Smith, 2005; Tack \& Vanderlinde, 2014), inviting teacher educators to exchange and reflect on their ideas and practices from different angles, mirrored by research, and improved by self-study.

\section{REFERENCES}

Berry, A. (2009). Professional self-understanding as expertise in teaching about teaching. Teachers and Teacher Education: Theory and Practice, 15(2), 305-318.

Boyd, P., Harris, K., Murray, J. (2011). Becoming a teacher educator: Guidelines for induction. Bristol, UK: The Higher Education Academy, ESCALATE. $2^{\text {nd }}$ ed.

Bullough, R.V. Jr. (2010). Parables, Storytelling, and Teacher Education. Journal of Teacher Education, 61(1-2), 153-160.

Churukian, G.A., Lock, C.R. (Eds.). (200o). International narratives on becoming a teacher educator: Pathways to a profession. Lewiston-New York: The Edwin Mellen Press.

Cochran-Smith, M. (2005). Teacher educators as researchers: Multiple perspectives. Teaching and Teacher Education, 21, 219-225.

Desimone, L.M. (2009). Improving impact studies of teachers' professional development: Toward better conceptualizations and measures. Educational Researcher, 38(3), 181-199.

European Commission (2013). Supporting teacher educators for better learning outcomes. Brussels: European Commission.

Evans, L. (2008). Professionalism, professionality and the development of education professionals. British Journal of Educational Studies, 56(1), 20-38.

Kelly, N., Clarà, M., Kehrwald, B., Danaher, P.A. (Eds.). (2016). Online learning networks for pre-service and early career teachers. London: McMillan Publishers.

Kennedy, A. (2005). Models of continuing professional development: A framework for analysis. Journal of In-service Education, 31 (2), 235-250.

Kirkpatrick, D.L. (1994). Evaluating training programs: The four levels. San Francisco: Berrett-Koehler.

Kitchen, J., Parker, D.C., Pushor, D. (Eds.). (2011). Narrative inquiries into curriculum making in teacher education. Bingley: Emerald Publishing. 
Koster, B., Dengerink, J., Korthagen, F., Lunenberg, M. (2008). Teacher educators working on their own professional development: Goals, activities and outcomes of a project for the professional development of teacher educators. Teachers and Teaching: Theory and Practice, $14(5), 567-587$.

Koster, B., Van den Berg, B. (2014). Increasing professional self-Understanding: Self-study research by teachers with the help of biography, core reflection and dialogue. Studying Teacher Education, 10(1), 86-100.

Loughran, J. (2006). Developing a pedagogy of teacher education: Understanding teaching \& learning about teaching. London: Routledge.

Loughran, J. (2011). On becoming a teacher educator. Journal of Education for Teaching, 37(3) 279-291.

Loughran J., Berry A. (2005). Modelling by teacher educators. Teaching and Teacher Education, 21, 193-203.

McEwan, H., Egan, K. (Eds.). (1995). Narrative in teaching, learning and research. New York: Teachers College Press.

Murray, J., Male, T. (2005). Becoming a teacher educator: Evidence from the field. Teaching and Teacher Education, 21, 125-142.

Ritter, J.K., Lunenberg, M., Pithouse-Morgan, K., Samaras, A.P., Vanassche, E. (Eds.). (2018). Teaching, learning, and enacting of self-study methodology: Unraveling a complex interplay. Singapore: Springer.

Shulman, L.S., Shulman, J.H. (2014). How and what teachers learn: A shifting perspective. Journal of Curriculum Studies, 36(2), 257-271.

Sjölie, E. (2014). The role of theory in teacher education: Reconsidered from a student teacher perspective. Journal of Curriculum Studies, 46(6), 729-750.

Smith, K. (2003). So, what about the professional development of teacher educators. European Journal of Teacher Education, 26(2), 201-215.

Smith, K. (2011). The multi-faceted teacher educator: A Norwegian perspective. Journal of Education for Teaching: International research and pedagogy, 37(3), 337-349.

Swennen, A., Lunenberg, M.L., Korthagen, F. (2008). Preach what you teach! Teacher educators and congruent teaching. Teachers and Teaching: Theory and Practice, 14(6), 531-542.

Swennen, A. Van der Klink. M. (Eds.). (2009). Becoming a teacher educator. Theory and practice for teacher educators. Dordrecht: Springer.

Swennen, A., Jones, K., Volman, M. (2010). Teacher educators: their identities, sub-identities and implications for professional development. Professional Development in Education, 36(1), 131-148.

Tack, H., Vanderlinde, R. (2014). Teacher educators' professional development: Towards a typology of teacher educators' researcherly disposition. British Journal of Educational Studies, 62(3), 297-315.

Van Velzen, C., Van der Klink, M., Swennen, A., Yaffe, E. (2010). The induction and needs of beginning teacher educators. Professional Development in Education, 36(1-2), 61-75.

Velov, (2012). The Flemish teacher educator profile. Retrieved from: https://velov.files.wordpress.com/2012/o2/velov_bro_en_111206.pdf

Wayne, A.J., Yoon, K.S., Zhu, P., Cronen, S., Garet, M.S. (2008). Experimenting with teacher professional development: Motives \& methods. Educational Researcher, 37 (8), 469-479.

Zeichner, K. (2005). Becoming a teacher educator: A personal perspective. Teaching and Teacher Education, 21, 117-124. 